\title{
Students' Perception on Social Media in Writing Class at STKIP Muhammadiyah Rappang, Indonesia
}

\author{
Geminastiti Sakkir ${ }^{1}$, Qashas Rahman ${ }^{2}$ \& Kisman Salija ${ }^{2}$ \\ ${ }^{1}$ English Education Department, STKIP Muhammadiyah Rappang, South Sulawesi, Indonesia \\ 2 English Education Department, State University of Makassar, UNM, Indonesia \\ Correspondence: Geminastiti Sakkir, English Education Department, STKIP Muhammadiyah Rappang, South \\ Sulawesi, Indonesia. E-mail: hj.geminastitisakkir@yahoo.com
}

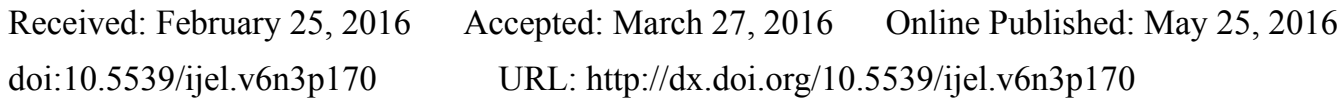

\begin{abstract}
Almost all students use social media, but few lecturers use it in their teaching process. This study examines students' perceptions of the use of social media in the process of teaching English in STKIP Rappang Muhammadiyah, South Sulawesi, Indonesia. This study was conducted using a mixed method, including quantitative and qualitative data. Data were collected using a questionnaire that collected background information of participants, a four-point Likert scale to gauge the students' perceived use of social media in class, and open-ended questions to gather more data rich in the beliefs, attitudes, wishes and concerns of students regarding the use of social media in the writing classroom. Findings from this study indicate that the majority of students showed a positive attitude toward and a willingness to use social media in the writing classroom. However, factors such as large classes, lack of training on the use of the Internet, and the lack of facilities could be possible barriers to the use of social media in the classroom.
\end{abstract}

Keywords: social media, teaching process, writing, Facebook

\section{Introduction}

The Writing skills are very important for every student learning the English language. Through the mastery of writing skills, students can communicate ideas, thoughts, feelings, and emotions to others in writing. For some people, communicating in written words is easier than communicating orally. Those people with difficulties communicating their ideas and feelings orally will be helped by the media writing. In addition to assisting the communication process, good writing skills will help learners to acquire better jobs. Today, many companies require mastery of good writing skills for prospective applicants. Each job requires employs to communicate effectively both orally and written. However, good writing skills are more necessary because almost all activities in companies involve writing, such as writing letters, e-mails, making presentation materials and reports, and others. Thus, it can be said that the skills writing is very important to the students. However, the reality does not match the expectations. The students' ability to write is still low. They still have many problems writing, such as spelling, punctuation, structure, organization, ideas, and others. Some students do not even know what they will and should write. Their interest and motivation to write is very low. They think writing is a very difficult thing. To overcome these problems, we need a strategy that is capable of building writing skill. This strategy is also expected to provide opportunities for the students to practice their writing skills. Not only in the form of controlled exercise but also activities that reflect real life. Technologies for writing that facilitate the flexible manipulation of text enable drafting and redrafting to occur easily, and the eventual product may be presented to a professional standard (Pennington, 2004). One of the chosen strategies to provide a medium that appeals to learners in writing involves social media. This media is expected to improve student interest and motivation in write.

The Internet can be used to support the process of writing as students develop their writing skills in various genres. Although the Internet is a naturally motivating tool and many young learners are familiar with using information technology, it is important for teachers to be active facilitators when the Internet is used for language learning. Since the Internet is multilingual, an obvious issue is how to make sure that students use English for their online tasks. Teachers who have never used blogs or social media for the development of process writing might feel lost about what steps to take to make the activities interactive and motivating. Fortunately, these 
instructors can consult widely available and user-friendly online resources to make the technology accessible. The social media tools offer excellent opportunities to conduct the pre-writing, drafting, peer review, and revising steps of the writing process (Boas, 2011).

The social media are computer-mediated tools that allow people to create, share idea, exchange information and pictures/videos in virtual communities and networks through the internet. Social media also is the collection of online communication channels dedicated to community-based input, interaction, content-sharing and collaboration. Social media are becoming an integral part of life online and have enabled changes in the way people live, work, interact and acquire knowledge and learning via the internet. Social media has emerged as a highly useful personal communication technology (Tess, 2013). Facebook is one of the latest examples of communications technologies that have been widely-adopted by students and, consequently, have the potential to become a valuable resource to support their educational communications and collaborations with faculty (Roblyer et al., 2010). MySpace (founded in 2003 by Tom Anderson \& Chris De Wolfe) and Facebook (founded in 2004 by Mark Zuckerberg, Dustin Moskovitz, \& Chris Hughes) have become two of the most popular sites on the Web (Maranto \& Barton, 2010). Social media can be used by language learners to explore new relationships rather than merely maintaining existing ones, helping to achieve a better understanding of the complex processes of mediation involved in online community formation and maintenance (Harrison \& Thomas, 2009). Ivala and Gachago (2012) found that appropriate use of blogs and Facebook groups, if accepted by students as a learning tool, enhance students' engagement in learning activities of an academic nature on- and off-campus.

Facebook, a social networking site launched in February 2004, is operated and owned by Facebook Inc. (Bihr \& Praus, 2008). This site is very popular among the people of the world in is widely used to make friends, share thoughts, chat, market products and campaign. Facebook users are not just students, but also the general public with various types of work. Based on observations and informal interviews conducted with learners, almost of all learners have a Facebook accounts and are active users. They are used to using media Facebook in daily activities. They take advantage of features that are owned by Facebook like a wall, notes, uploading images and video, and chat. Features that are owned by Facebook can actually be used in learning activities, including learning to write. However, to be able to use Facebook for learning, faculty and students must have a Facebook account. The phenomenon of Facebook use among students is high. With today's technological advances students rarely use textbooks as a means to accomplish these tasks given by the lecturer.

They frequently use the Internet instead. With the internet they can access what they need easily and quickly. Students use Facebook communications media not only to perform tasks or even add information, but also to develop writing skills. Students of journalism in particular can benefit from using Facebook to hone writing skills, because many writings placed on weblogs have room for comments in when they read the writing they can comment on the posts. In this way, students can learn how to express their opinions in writing. In general, students often use the alternative that is easy, fast and reliable. Although there are books or other media that can be used as a medium of learning they find it easier using Facebook. With Facebook, students can obtain the needed information or knowledge. The students believe Facebook can be utilized as an online environment to facilitate the learning of English.

Nevertheless, teachers or language instructors have to integrate Facebook as an educational project with predetermined learning objectives and outcomes for the learning experience to be meaningful (Kabilan, Ahmad, \& Abidin, 2010). The materials obtained through the internet must be well selected and then appropriate to the needs. Facebook is not only used for tasks, but students can also use Facebook as a place for learning to write. Facebook is an effective tool for improving the students' writing skills, especially in the brainstorming of ideas before the actual writing (Yunus \& Salehi, 2012). In this way it can be seen that the role of Facebook for students is very important. But, before conducting research about how to improve students' writing skills through social media especially Facebook, first must we know the students' perspectives of social media in the classroom. Students' perspectives include their beliefs, attitudes, willingness, and concerns regarding the use of social media in the writing class.

This study aims at answering the following questions:

1) What are students' perceptions on the use of Social Media in the classroom?

2) What are the factors affecting the use of Social Media in the classroom?

\section{Method}

The subjects in the study were 42 EFL students of third semester ( 35 females' $83.33 \%$ and 7 males $16.67 \%$ ). The age range of the students was from 26-60 with a mean age of under 25. Their learning English experience ranged 
from less than 5 years to more than 25 years with a mean of 8 years. The study used a questionnaire to examine students' perceptions on the use of social media in writing class. The questionnaire (Shin \& Son, 2007) consisted of three sections: a demographic section to get the students background information, a multiple- choice section to find their perceptions on the use of social media using four- point Likert scale of strongly disagree (1), disagree (2), agree (3), and strongly agree (4), and an open- ended question section to investigate their general opinions or comments on the use of social media in writing class. It was distributed on all the third semester students of STKIP Muhammadiyah Rappang, English Education Department of 2014/ 2015 academic year. From total 60 students of the semester, 42 students completed the questionnaire had been returned within a week. The data collected from the questionnaire were analyzed quantitatively and qualitatively.

\section{Results and Discussion}

The results of the students' answer to the second section of the questionnaire are shown in Table 1. The majority of students agreed that electronic Social Media is useful for learning writing English, students can be motivated by the use of electronic Social Media, and they can improve their English writing skill through the use of the electronic Social Media (80.95\%). As regarding the question that students can improve communication skills by emailing or chatting with native speakers of English electronic Social Media and students will be more attentive in Internet- assisted English language teaching classes, $78.57 \%$ of the students answer agreed. To the question of electronic Social Media tools can be used for learning writing English purposes, $78.56 \%$ of the students agreed. As to the question, students can learn how to use electronic social Media resources for learning English for themselves, $73.81 \%$ of the students showed their agreement. However, the students gave strong positive answers to the usefulness of the electronic Social Media provides non-native speakers of English with a rich learning environment (66.67\%). Most of them also indicated that the electronic Social Media can replace textbooks and easy to find and share materials on it $(59.52 \%)$. Fortunately, there is not disagreement with some items was found. In all of item, the students answer fewer than $50 \%$ in showing their disagreements.

Table 1. Students' responses to the questionnaire items

\begin{tabular}{|c|c|c|c|c|c|c|}
\hline NO & Statements & SD (1) & D (2) & A (3) & SA (4) & Mean \\
\hline 1 & $\begin{array}{l}\text { The Electronic Social Media provides } \\
\text { non-native speakers of English with a rich } \\
\text { learning environment. }\end{array}$ & $1(2.38 \%)$ & $12(28.57 \%)$ & $28(66.67 \%)$ & - & 2.60 \\
\hline 2 & $\begin{array}{l}\text { Electronic Social Media tools can be used } \\
\text { for learning writing English purposes. }\end{array}$ & $3(7.14 \%)$ & $5(11.90 \%)$ & $27(64.28 \%)$ & $6(14.28 \%)$ & 2.81 \\
\hline 3 & $\begin{array}{l}\text { Electronic Social Media resources can } \\
\text { replace textbooks. }\end{array}$ & $14(33.33 \%)$ & $2(4.76 \%)$ & $25(59.52 \%)$ & - & 2.21 \\
\hline 4 & $\begin{array}{l}\text { It is easy to find and share ESL/EFL } \\
\text { materials on the Electronic Social Media. }\end{array}$ & $6(14.28 \%)$ & $5(11.90 \%)$ & $14(33.33 \%)$ & $11(26.19 \%)$ & 2.43 \\
\hline 5 & $\begin{array}{l}\text { Electronic Social Media is useful for } \\
\text { learning writing English. }\end{array}$ & $1(2.38 \%)$ & $6(14.28 \%)$ & $27(64.28 \%)$ & $7(16.67 \%)$ & 2.90 \\
\hline 6 & $\begin{array}{l}\text { Students can be motivated by the use of the } \\
\text { Electronic Social Media in the classroom. }\end{array}$ & $2(4.76 \%)$ & $6(14.28 \%)$ & $27(64.28 \%)$ & $7(16.67 \%)$ & 2.93 \\
\hline 7 & $\begin{array}{l}\text { Students can improve their English writing } \\
\text { skill through the use of the Electronic } \\
\text { Social Media }\end{array}$ & $1(2.38 \%)$ & $7(16.67 \%)$ & $27(64.28 \%)$ & $7(16.67 \%)$ & 2.95 \\
\hline 8 & $\begin{array}{l}\text { Students can learn how to use Electronic } \\
\text { Social Media resources for learning English } \\
\text { for themselves. }\end{array}$ & $5(11.90 \%)$ & $7(16.67 \%)$ & $23(54.76 \%)$ & $8(19.05 \%)$ & 2.86 \\
\hline 9 & $\begin{array}{l}\text { Students can improve communication skills } \\
\text { by emailing or chatting with native } \\
\text { speakers of English Electronic Social } \\
\text { Media. }\end{array}$ & $2(4.76 \%)$ & $6(14.28 \%)$ & $15(35.71 \%)$ & $18(42.86 \%)$ & 3.12 \\
\hline 10 & $\begin{array}{l}\text { Students will be more attentive in } \\
\text { Internet-assisted English language learning } \\
\text { classes. }\end{array}$ & $1(2.38 \%)$ & $3(7.14 \%)$ & $31(73.81 \%)$ & $2(4.76 \%)$ & 2.57 \\
\hline
\end{tabular}

Note. SD: Strongly Disagree D: Disagree A: Agree SA: Strongly Agree

The results of the questionnaire in section 1 (one) showed that the majority of the students (95.24\%) have access to internet in their home. About $76.19 \%$ of the students used the internet in learning purposes, especially in 
writing and reading class $(38.10 \%)$. Of the 32 students used the internet, 15 students used the internet less than five hours a week. They usually used social media, online dictionary, web surfing and games. The students who did not use the internet in the classroom (23.81\%) also hope to use social media, encyclopedia and web surfing $(35.71 \%)$.

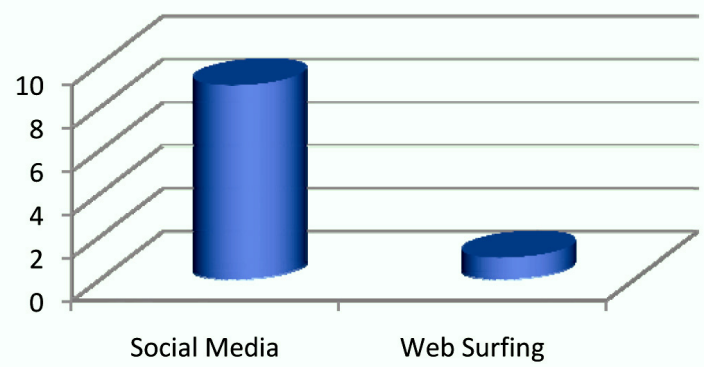

Figure 1. Types of the Internet activities students hope to apply in classroom $(\mathrm{N}=10)$

The 10 students non-user internet in classroom gave reasons in the following order: limited computer skill, limited interest, limited English ability (7.14\%) and limited computer facilities (16.67\%). Only one of the students did not familiar with electronic social media. Almost of $97.62 \%$ the students who familiar with electronic social media use it more than five hours a week (42.85\%). The types of electronic social media activities that the students usually used were Facebook, blackberry messenger, twitter, text chatting, email, and on-line blog.

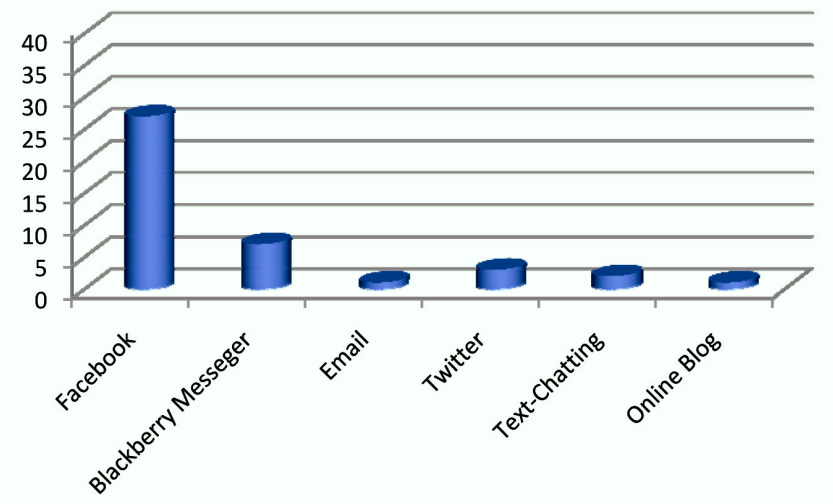

Figure 2. Social media activities that students usually used in the classroom $(\mathrm{N}=41)$

Only seven of the students showed that they had taken any training course to learn how to use the internet, and most of them $(64.29 \%)$ hope to participate in training course in the future. The big reason why they did not take the course because cost $(23.81 \%)$ and distance to training course $(21.43 \%)$. Through the open-ended questions (the section 3) in the questionnaire, the students indicated some advantages of using electronic social media in the writing English classroom as follows: Students can get much information about their assignment; they have much resource about material learning so that it can improve their knowledge.

The lecturer not difficulties to explain their material for students, so students can explore their argument; make students simply in learning process and easy study; easy communication; the students can train the ability to write with use information that in electronic social media; the students can be free write anything in our mind, with spontan, and can get much information as well as can get give critic from another; Some people usually use it for search something important for example, they are use it for search about what is the real purpose of English learning or search how to improve our language; Using social media in the classroom can make easy to get information or material for writing English. In other that, in social media we also discuss about our writing English; students can share with friends their writing; students can communicate with their lecture, how to make a good writing; the students can search Mozilla Firefox look for Google translate if you don't have many 
vocabulary, you can use Google translate for translate your word English to Indonesia or Indonesia to English, and then you can search if you have work about writing because electronic social media make your work is easy.

However, some of the students mentioned the disadvantages of using electronic social media in the writing English classroom. Their answers included: the students just using social media for access Facebook, etc. they just busy with their Facebook so they not attend about material learning; the students not focus in learning; social media can be a bad influence it misused, for example using Facebook and chat when the lesson is in progress and can interfere with concentration; the students not focus because many students used electronic social media in the learning time for personal problem; with of using the electronic social media you will be lazy to your opinion, not creative. Many students copy-paste data in internet if any homework from lecturer, so that the student not creative; using English social media in the classroom can make the student is not focus to finish the task; and make the students be lazy people because social media make easy to get information and material writing; it's so easy to found information. So that we too lazy to use opinion; using the electronic social media in the writing English classroom is can be disturb your concentration because you want always to use electronic social media; students do not use electronic social media to writing; students do not focus for writing; there are many lecture cannot use electronic social media; student not focus if often use social media; some student not understand the social media; cost and sometime is unavailable; it can make students lazy and can make students can't increase and expand their mind or horizon because they never try to think to solve their homework (problem about lesson) just search in Google; using the electronic social media in the writing English classroom is the language in electronic social media can be disturb the way of writing correctly.

Finally, the students made some comments on the use of the electronic social media for the learning writing English as a foreign language in STKIP Muhammadiyah Rappang. These comments can be summarized as follows: I think it's good, students can easy to search material learning in social media, but in STKIP Muhammadiyah Rappang using internet is limited access; I think used the electronic social media for writing English can be help process student for finish task and can share information material. I think it good, but connection of internet in this college not too bad; the electronic social media can help you of learning; it's easy and has fun; it's good for the learning writing English but access internet in the collage is bad; It is can give positive effect because it can improve students' skills; this is very good but in STKIP Muhammadiyah Rappang not yet applies; I think using electronic social media is not effective because the students can't try to writing for their brain, but they will use to internet.

\section{Conclusion}

The research concluded that students have positive perceptions of the use of social media in writing class, but some factors influence the implementation. The biggest limiting factors are the access to the internet on the STKIP Muhammadiyah Rappang campuss. So, this problem must be reduced by repairing the Internet network and adding capacity. Using technology during the learning process requires substantial investments of time, financial support, equipment, personal commitment and courage in order to explore teaching innovation in the EFL classrooms (Angers \& Machtmes, 2005).

The majority of students also showed a willingness to use social media in the writing classroom. However, factors such as large classes, lack of training on the use of the Internet, and the lack of facilities could be possible barriers to the use of social media in the classroom. Facebook helps reduce barriers such as the lower self-esteem that students might experience in forming the kinds of large, heterogeneous networks that are sources of bridging social capital (Steinfield, Ellison, \& Lampe, 2008). Students gave positive feedback saying that social media is the interesting way to learn writing process.

\section{Acknowledgments}

The researcher adress thanks to Ministry of Research, Technology and Hinger Education of Indonesia for the financial support (PKPI Program 2015), State University of Makassar, Northern Illinois University and STKIP Muhammadiyah Rappang.

\section{References}

Angers, J., \& Machtmes, K. L. (2005). An ethnographic-case study of beliefs, context factors, and practices of teachers integrating technology. The Qualitative Report, 10(4), 771-794.

Boas, I. V. (2011). Process Writing and the Internet: Blogs and Ning Networks in the Classroom. English Teaching Forum, 49(2), 26-33.

DePew, K. E. (2011). Social media at academia's periphery: Studying multilingual developmental writers' Facebook composing strategies. Reading Matrix: An International Online Journal, 11(1). 
Harrison, R., \& Thomas, M. (2009). Identity in online communities: Social networking sites and language learning. International Journal of Emerging Technologies and Society, 7(2), 109-124.

Ivala, E., \& Gachago, D. (2012). Social media for enhancing student engagement: the use of Facebook and blogs at a university of technology. South African Journal of Higher Education, 26(1), 152-167.

Kabilan, M. K., Ahmad, N., \& Abidin, M. J. Z. (2010). Facebook: An online environment for learning of English in institutions of higher education? The Internet and Higher Education, 13(4), 179-187. http://dx.doi.org/10.1016/j.iheduc.2010.07.003

Maranto, G., \& Barton, M. (2010). Paradox and promise: My Space, Facebook, and the sociopolitics of social networking in the writing classroom. Computers and Composition, 27(1), 36-47. http://dx.doi.org/10.1016/j.compcom.2009.11.003

Pennington, M. (2004). Electronic media in second language writing: An overview of tools and research findings. New perspectives on CALL for second language classrooms (pp. 69-92).

Rathert, S., \& Okan, Z. (2015). Writing for publication as a tool in teacher development. ELT Journal, ccv029. http://dx.doi.org/10.1093/elt/ccv029

Roblyer, M., McDaniel, M., Webb, M., Herman, J., \& Witty, J. V. (2010). Findings on Facebook in higher education: A comparison of college faculty and student uses and perceptions of social networking sites. The Internet and Higher Education, 13(3), 134-140. http://dx.doi.org/10.1016/j.iheduc.2010.03.002

Shin, H. J., \& Son, J. B. (2007). EFL teachers' perceptions and perspectives on Internet-assisted language teaching. Computer-Assisted Language Learning Electronic Journal (CALL-EJ), 8(2).

Sorapure, M. (2010). Information visualization, web 2.0, and the teaching of writing. Computers and Composition, 27(1), 59-70. http://dx.doi.org/10.1016/j.compcom.2009.12.003

Steinfield, C., Ellison, N. B., \& Lampe, C. (2008). Social capital, self-esteem, and use of online social network sites: A longitudinal analysis. Journal of Applied Developmental Psychology, 29(6), 434-445. http://dx.doi.org/10.1016/j.appdev.2008.07.002

Tess, P. A. (2013). The role of social media in higher education classes (real and virtual) - A literature review. Computers in Human Behavior, 29(5), A60-A68. http://dx.doi.org/10.1016/j.chb.2012.12.032

Vie, S. (2008). Digital divide 2.0: "Generation M" and online social networking sites in the composition classroom. Computers and Composition, 25(1), 9-23. http://dx.doi.org/10.1016/j.compcom.2007.09.004

Warschauer, M., \& Healey, D. (1998). Computers and language learning: An overview. Language teaching, 31(2), 57-71. http://dx.doi.org/10.1017/S0261444800012970

Yunus, M. M., \& Salehi, H. (2012). The effectiveness of Facebook groups on Teaching and Improving Writing: Students' perceptions. Journal of Education and Information Technologies, 1(6), 87-96.

Zaidieh, A. J. Y. (2012). The use of social networking in education: challenges and opportunities. World of Computer Science and Information Technology Journal (WCSIT), 2(1), 18-21.

\section{Copyrights}

Copyright for this article is retained by the author(s), with first publication rights granted to the journal.

This is an open-access article distributed under the terms and conditions of the Creative Commons Attribution license (http://creativecommons.org/licenses/by/3.0/). 